\title{
Analysis of Factors That Affecting to Human Development Index in North Sumatra
}

\author{
Nadya Wiandita Pardede ${ }^{1}, \operatorname{Irsad}^{2}$, Rujiman $^{3}$ \\ ${ }^{1}$ Posgraduate Students, Faculty of Economics and Business, Department of Economics, Universitas Sumatra \\ Utara, Indonesia \\ ${ }^{2,3}$ Postgraduate Lecturer, Faculty of Economics and Business, Department of Economics, Universitas Sumatra \\ Utara, Indonesia
}

Corresponding Author: Nadya Wiandita Pardede

\begin{abstract}
This research is to determine human development index in North Sumatra. The research used quantitative method and the data consisted of secondary data obtained directly from Statistics of North Sumatra. The research objects were 33 districts/towns in North Sumatra. This study uses secondary data obtained directly from Statistics of North Sumatra. The research used panel data, the combination of time series and cross section data within 6 years, from 2014 until 2019. Variables used are Economic Growth, Poverty and Direct Expenditure per Capita. Analysis method in this research using Fixed Effect Model (FEM) using Eviews 10 as an estimation tool. The results showed that Economic Growth has a significant negative effect on Human Development Index, Poverty has a significant negative on Human Development Index and Direct Expenditure per Capita has a significant positif on Human Development Index. Then the relationship between Economic Growth, Poverty and Direct Expenditure per Capita with Human Development Index97,70\% and 2,30\% other explained by other factors not mentioned in this model.
\end{abstract}

Keywords: Human Development Index, Economic Growth, Poverty, Direct Expenditure per Capita

\section{INTRODUCTION}

Regional economic development is the process by which the local government and the whole society to manage the various resources that exist and formed a partnership to create new jobs and encourage the development of economic activities in the area (Kuncoro, 2004). Development of a country or region marked by some economic activities such as increased productivity and increased per capita income thereby increasing the level of well-being. However, development also brings problems and new demands such as social inequality, quality of life, employment opportunities, human rights, environment and others. As is known, the implementation of the construction of the emphasis on the concept of economic growth, and assume that economic growth will benefit the human. But in reality it is not always thus, in the long-term high economic growth is important but economic growth how and for whom (Yusri, 2010).

In the construction in line with the implementation of regional autonomy need for a new paradigm, namely the development of more emphasis on aspects of human development. Human development requires improving the quality of life of residents both physically, mentally and spiritually. Ahead of the 1990's, the world's attention turned to economic development into human development (BPS, 2019). The international world began to realize that the man is the input and the goal of development. This happens because of the economic growth high in some countries but is also accompanied by high unemployment and poverty, low level of 
health, and social problems associated with human (BPS, 2018). In 1990, the United Nations Development Program published a report to respond to the issues which are being developed at that time. In a report entitled Human Development Report in 1990, the United Nations Development Program asserted that the human being is the wealth of the nation. Therefore, the main purpose of development is to create an enabling environment for people to enjoy long life, healthy, and live a productive life. The first edition of the report Human Development Report emphasizes the importance of the development of humanoriented. This shows that the human development actually looked human as final destination, as well as a input development (BPS, 2019).

\section{United Nations Development} Programme, 1995 defines human development as "a process of enlarging people's choices". That is, that human development is a process to expand the options for the residents. The United Nations Development Program introduced a new idea in the measurement of human development that is referred to as the Human Development Index. Since that time, the Human Development Index published periodically in the annual report of the Human Development Report. The Human Development index and explain how the resident can access the results of development in earned income, health, education, and other aspects in life.

The Human Development index is used to see the progression of human development in a country or area. The Human Development index, the highest of all countries, namely Norway with 0,958 in the category of very high. Based on the 2019 Human Development Index Ranking, the following ten countries by the Human Development Index, the highest of all countries, namely: 1) Norway 2) Switzerland 3) Ireland, 4) Germany, 5) Hongkong, 6) Australia, 7) Iceland, 8) Sweden, 9) of Singapore, and 10) the Netherlands. Indonesia itself is included in the category of 'high', was ranked 111 namely 0,707 . If compared to other ASEAN countries, Indonesia is ranked 6.

Table 1.1 The Human Development index Countries of ASEAN 2019

\begin{tabular}{|l|l|l|l|}
\hline ASEAN Ranking & $\begin{array}{l}\text { Global } \\
\text { Ranking }\end{array}$ & Country & IPM \\
\hline 1 & 9 & Singapura & 0,935 \\
\hline 2 & 43 & Brunei Darussalam & 0,845 \\
\hline 3 & 61 & Malaysia & 0,804 \\
\hline 4 & 77 & Thailand & 0,765 \\
\hline 5 & 106 & Filipina & 0,712 \\
\hline 6 & 111 & Indonesia & 0,707 \\
\hline 7 & 118 & Vietnam & 0,693 \\
\hline 8 & 140 & Laos & 0,604 \\
\hline 9 & 145 & Myanmar & 0,584 \\
\hline 10 & 146 & Kamboja & 0,581 \\
\hline
\end{tabular}

Based on data from the Central bureau of Statistics, the Index of Human Development in Indonesia in the year 2019 amounted to 71,92 increase of 0.53 compared to the year 2018. 71,39. The quality of health, education, and fulfilling the needs of the people of Indonesia have increased.

The achievement of Human Development Index in Indonesia is the highest occupied by the Province of DKI Jakarta by 80,76 , while the achievement of the lowest occupied by the Province of Papua to 60.84. Although still low, the achievements of the Human Development Index of Papua Province changed its status from low to medium since the previous year. Human development in North Sumatra continues to increase every year. North Sumatra is ranked 12 by the Human Development Index reached 71,74. This figure increased by 0.56 percent or grew by $0.79 \%$ to compared to 2018 .

The achievement of human development is measured by considering three aspects: health (life expectancy), education (hope the old school, the average old school) and expenses. Babies born in North Sumatra in 2019 have hope to be able to live up to 68,95 years, longer 0,34 year compared to the previous year. Children in 2019 7-year-old hopes can enjoy education for 13,15 years, longer 0,01 year compared to the year 2018. The population age 25 years and above on average have been 
studying for at 9.45 years, longer of 0.11 year over the previous year. Then the community of North Sumatra in the year 2019 meet the needs of life with average per capita expenditure of Rp.10.649.000 per year, an increase of Rp.258.000 compared to the previous year.

Table 1.2 The Human Development index Indonesia 2018-2019 (Index)

\begin{tabular}{|c|c|c|c|c|c|c|c|c|c|c|}
\hline \multirow[b]{2}{*}{ Province } & \multicolumn{2}{|c|}{$\begin{array}{l}\text { Life Expectancy At } \\
\text { Birth (Years) }\end{array}$} & \multicolumn{2}{|c|}{$\begin{array}{l}\text { Hope The Old } \\
\text { School (Year) }\end{array}$} & \multicolumn{2}{|c|}{$\begin{array}{l}\text { The Average Length Of } \\
\text { The School (Year) }\end{array}$} & \multicolumn{2}{|c|}{$\begin{array}{l}\text { Per } \quad \text { Capita } \\
\text { expenditure (Rp.) }\end{array}$} & \multicolumn{2}{|l|}{ IPM } \\
\hline & 2018 & 2019 & 2018 & 2019 & 2018 & 2019 & 2018 & 2019 & 2018 & 2019 \\
\hline Aceh & 69.64 & 69.87 & 14.27 & 14.30 & 9.09 & 9.18 & 9186 & 9603 & 71.19 & 71.90 \\
\hline Sumatra Utara & 68.61 & 68.95 & 13.14 & 13.15 & 9.34 & 9.45 & 10391 & 10649 & 71.18 & 71.74 \\
\hline Sumatra West & 69.01 & 69.31 & 13.95 & 14.01 & 8.76 & 8.92 & 10638 & 10925 & 71.73 & 72.39 \\
\hline Riau & 71.19 & 71.48 & 13.11 & 13.14 & 8.92 & 9.03 & 10968 & 11255 & 72.44 & 73.00 \\
\hline Jambi & 70.89 & 71.06 & 12.90 & 12.93 & 8.23 & 8.45 & 10357 & 10592 & 70.65 & 71.26 \\
\hline Sumatra Selatan & 69.41 & 69.65 & 12.36 & 12.39 & 8.00 & 8.18 & 10652 & 10937 & 69.39 & 70.02 \\
\hline Bengkulu & 68.84 & 69.21 & 13.58 & 13.59 & 8.61 & 8.73 & 10162 & 10409 & 70.64 & 71.21 \\
\hline Lampung & 70.18 & 70.51 & 12.61 & 12.63 & 7.82 & 7.92 & 9858 & 10114 & 69.02 & 69.57 \\
\hline Kep. Bangka Belitung & 70.18 & 70.50 & 11.87 & 11.94 & 7.84 & 7.98 & 12666 & 12959 & 70.67 & 71.3 \\
\hline Kep. Riau & 69.64 & 69.80 & 12.82 & 12.83 & 9.81 & 9.99 & 13976 & 14466 & 74.84 & 75.48 \\
\hline DKI Jakarta & 72.67 & 72.79 & 12.95 & 12.97 & 11.05 & 11.06 & 18128 & 18527 & 80.47 & 80.76 \\
\hline Jawa West & 72.66 & 72.85 & 12.45 & 12.48 & 8.15 & 8.37 & 10790 & 11152 & 71.30 & 72.03 \\
\hline Jawa Tengah & 74.18 & 74.23 & 12.63 & 12.68 & 7.35 & 7.53 & 10777 & 11102 & 71.12 & 71.73 \\
\hline DI Yogyakarta & 74.82 & 74.92 & 15.56 & 15.58 & 9.32 & 9.38 & 13946 & 14394 & 79.53 & 79.99 \\
\hline Jawa Timur & 70.97 & 71.18 & 13.10 & 13.16 & 7.39 & 7.59 & 11380 & 11739 & 70.77 & 71.50 \\
\hline Banten & 69.64 & 69.84 & 12.85 & 12.88 & 8.62 & 8.74 & 11994 & 12267 & 71.95 & 72.44 \\
\hline Bali & 71.68 & 71.99 & 13.23 & 13.27 & 8.65 & 8.84 & 13886 & 14146 & 74.77 & 75.38 \\
\hline Nusa TenggaraWest & 65.87 & 66.28 & 13.47 & 13.48 & 7.03 & 7.27 & 10284 & 10640 & 67.30 & 68.14 \\
\hline Nusa Tenggara Timur & 66.38 & 66.85 & 13.10 & 13.15 & 7.30 & 7.55 & 7566 & 7769 & 64.39 & 65.23 \\
\hline Kalimantan West & 70.18 & 70.56 & 12.55 & 12.58 & 7.12 & 7.31 & 8860 & 9055 & 66.98 & 67.65 \\
\hline Kalimantan Tengah & 69.64 & 69.69 & 12.55 & 12.57 & 8.37 & 8.51 & 10931 & 11236 & 70.42 & 70.91 \\
\hline Kalimantan Selatan & 68.23 & 68.49 & 12.50 & 12.52 & 8.00 & 8.20 & 12062 & 12253 & 70.17 & 70.72 \\
\hline Kalimantan Timur & 73.96 & 74.22 & 13.67 & 13.69 & 9.48 & 9.70 & 11917 & 12359 & 75.83 & 76.61 \\
\hline Kalimantan Utara & 72.50 & 72.54 & 12.82 & 12.84 & 8.87 & 8.94 & 8943 & 9343 & 70.56 & 71.15 \\
\hline Sulawesi Utara & 71.26 & 71.58 & 12.68 & 12.73 & 9.24 & 9.43 & 10731 & 11115 & 72.20 & 72.99 \\
\hline Sulawesi Tengah & 67.78 & 68.23 & 13.13 & 13.14 & 8.52 & 8.75 & 9488 & 9604 & 68.88 & 69.50 \\
\hline Sulawesi Selatan & 70.08 & 70.43 & 13.34 & 13.36 & 8.02 & 8.26 & 10814 & 11118 & 70.90 & 71.66 \\
\hline Sulawesi Tenggara & 70.72 & 70.97 & 13.53 & 13.55 & 8.69 & 8.91 & 9262 & 9436 & 70.61 & 71.20 \\
\hline Gorontalo & 67.45 & 67.93 & 13.03 & 13.06 & 7.46 & 7.69 & 9839 & 10075 & 67.71 & 68.49 \\
\hline Sulawesi West & 64.58 & 64.82 & 12.59 & 12.62 & 7.50 & 7.73 & 9051 & 9235 & 65.10 & 65.73 \\
\hline Maluku & 65.59 & 65.82 & 13.92 & 13.94 & 9.58 & 9.81 & 8721 & 8887 & 68.87 & 69.45 \\
\hline Maluku Utara & 67.80 & 68.18 & 13.62 & 13.63 & 8.72 & 9.00 & 7980 & 8308 & 67.76 & 68.70 \\
\hline Papua West & 65.55 & 65.90 & 12.53 & 12.72 & 7.27 & 7.44 & 7816 & 8125 & 63.74 & 64.70 \\
\hline Papua & 65.36 & 65.65 & 10.83 & 11.05 & 6.52 & 6.65 & 7159 & 7336 & 60.06 & 60.84 \\
\hline Indonesia & 71.20 & 71.34 & 12.91 & 12.95 & 8.17 & 8.34 & 11059 & 11299 & 71.39 & 71.92 \\
\hline
\end{tabular}

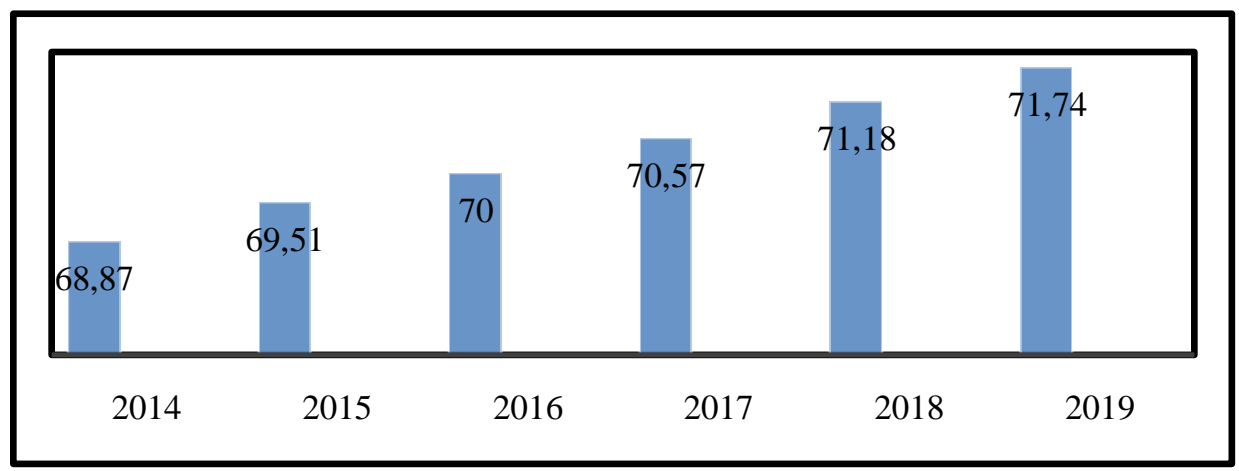

Source: The Central Bureau Of Statistics North Sumatra, 2020

Figure 1.1 the Human Development Index (HDI) of North Sumatra 2014-2019

Based on the chart above, the Human Development Index North Sumatra increased from 68,87 in 2014 to 71,74 in 2019. During the period of 2014 to 2019 , the Human Development Index North Sumatra shows the progress and status of human development in North Sumatra has increased. Human development, North 
Sumatra have been of high status starting in 2016. Human development can be said to be high if The Construction of the Human above 70 . While during the period of 2014 to 2015 human development Sumatra Utara only the status is. The Human Development index of North Sumatra in 2014 amounted to 68,87 and in 2015 amounted to 69,51 .

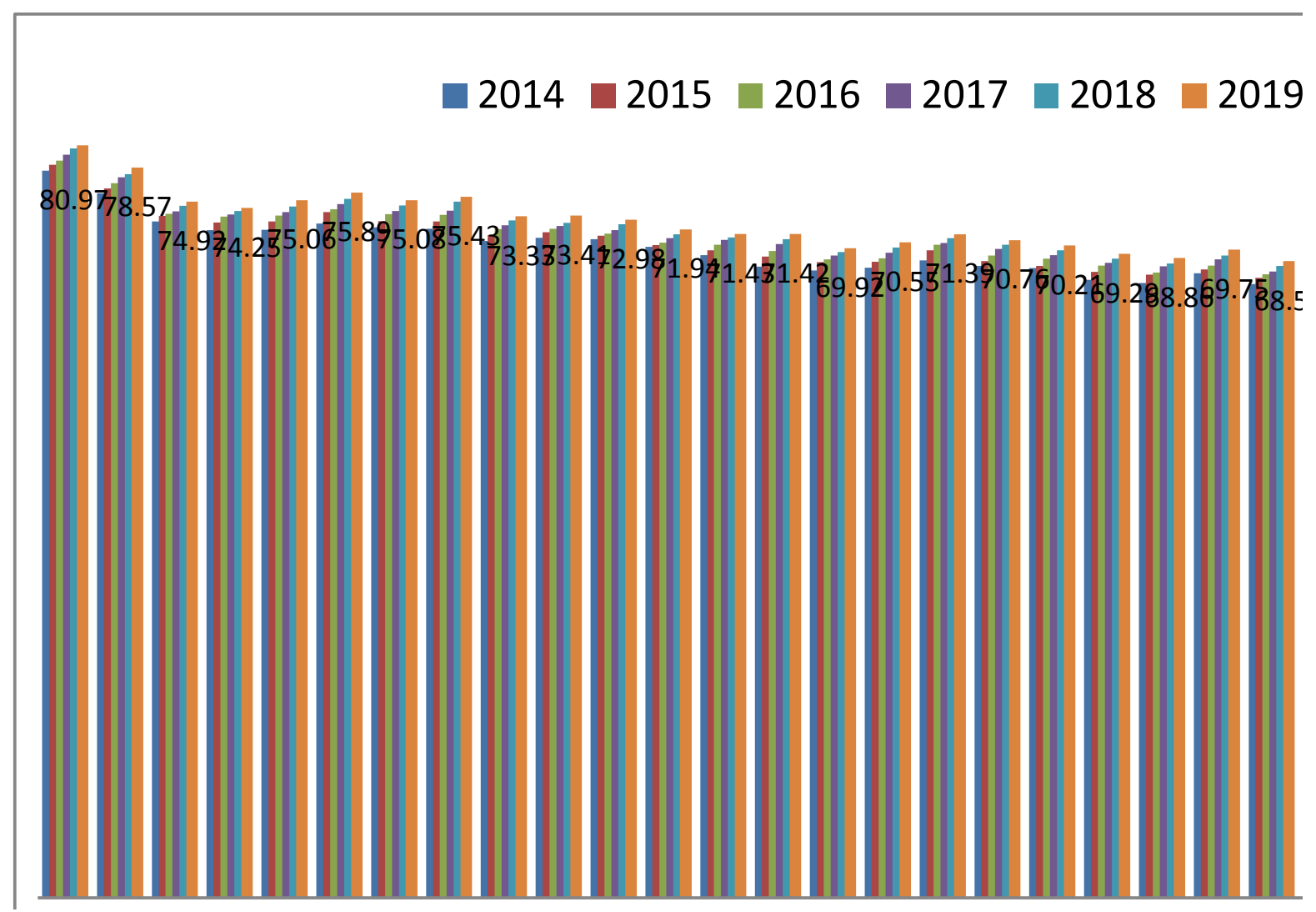

Source: The Central Bureau Of Statistics North Sumatra

Figure 1.2 Human Development Index (HDI) Sumatra Utara Distric / Kota 2014-2019

Based on the above chart of the Human Development Index North Sumatra District /City, in the years 2014 - 2019 Human Development Index which the highest is the City of Medan. On the 2019 Human Development Index Medan City status was very high at of 80.97 with the growth of $0,40 \%$ compared to the year 2018 amounted to 80,65 and the lowest Human Development Index is Nias West of 61,14 with the growth of 1.19 percent from the year 2018 amounted to 60,42. More things need to be considered in addition to the HDI figures is the speed of human development, which is seen from the growth of the HDI. In the year 2018-2019, North Nias Regency occupies the first position with the growth of the HDI amounted to $1.47 \%$, followed by the City of Gunungsitoli of $1.42 \%$ and the South Nias Regency of $1.38 \%$. On the other hand, there is a District with the growth of the Human Development Index which is slow in North Sumatra. During the year 2018 - 2019, the growth of the Human Development Index in the City of Medan, namely to $0.40 \%$. Followed the growth of the Human Development Index Karo 0.46\% and Pematang Siantar City with the growth of 0.49 percent. District/City with the growth of the Human Development Index which later can be also due to the Human Development Index of the previous year is already high, then the speed of the development of human tends to slow down. On the contrary, if the achievement of human development in a region is still low, the growth of the construction of the human tends to be more fast compared to other regions (BPS, 2018). 
The reason why the construction of the human need attention are: first, many developing countries including Indonesia, which managed to achieve high economic growth, but failed to reduce socio-economic inequality and poverty. Second, many developed countries that have the high income level turns out not managed to reduce social problems such as: drug abuse, AIDS, alcohol, homeless, and domestic violence. Third, some low-income countries are able to achieve the level of human development that high because it is able to use wisely all the resources to develop the basic human ability (UNDP, 1990).

One indicator of the success of the implementation of the pembangunanyang can be used as a benchmark in the macro is the growth of ekonomiyang mirrored from the growth of Gross Regional Domestic
Product in a region. The high economic growth of a region indicates the better activities or the economic performance of the areas that can be seen from the growth of GDP at constant prices (Todaro,2006). Economic development done by the a the country aims to realize a society prosperous, prosperous and fair. According to the theory of economic growth Kuznets, one of the characteristics of the growth of the modern economy is the high growth of output per capita (Todaro, 2003:99). The increasing economic growth change in consumption patterns due to increased purchasing power. The high purchasing power of society will increase the Human Development Index because the purchasing power of the community is a component in forming the Human Development Index.

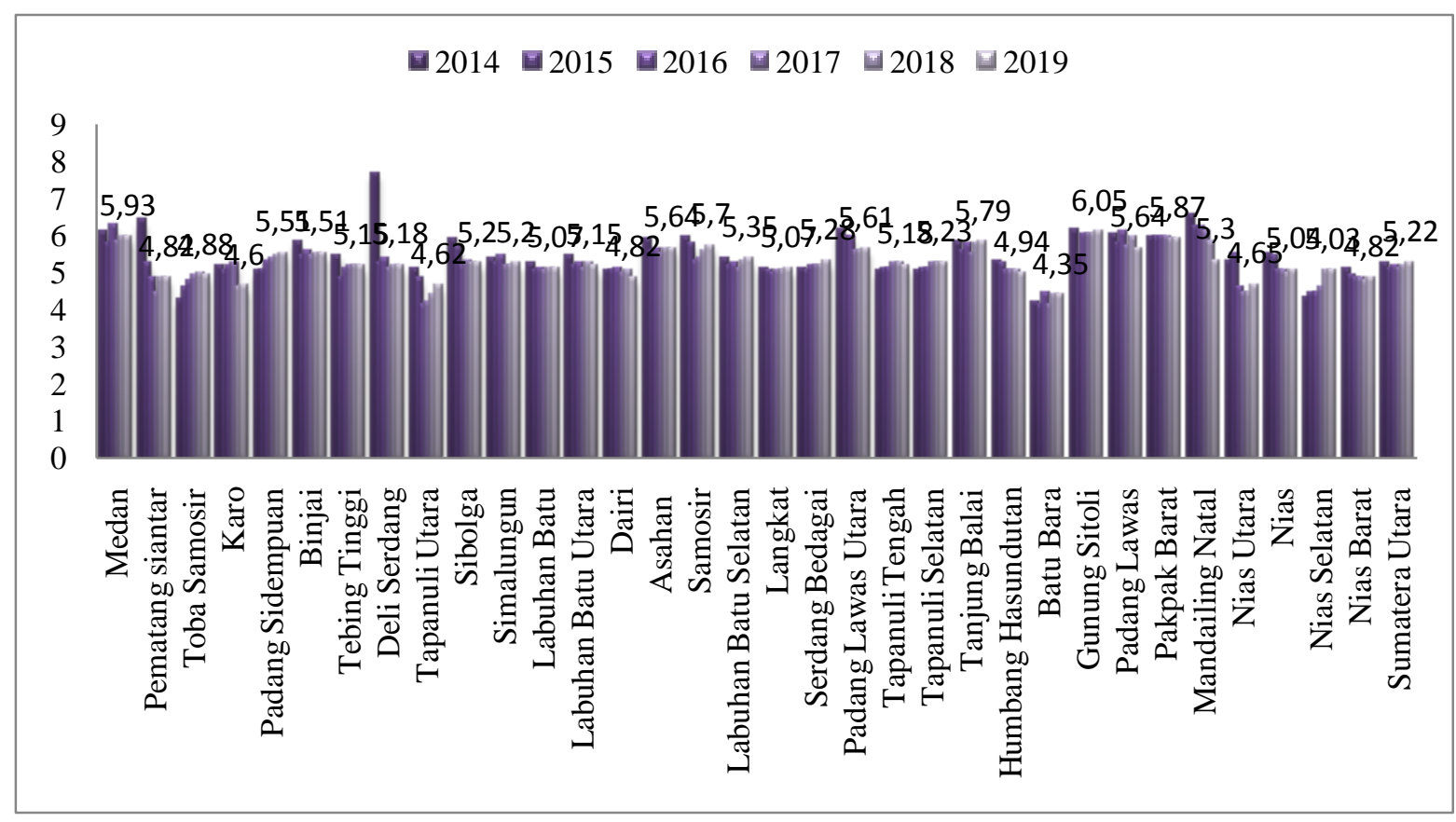

Source: The Central Bureau Of Statistics North Sumatra, 2020

Figure 1.3 Growth of the Economy of North Sumatra per District/City on the Basis of Price Constant 2014-2019 (Percent)

Based on the chart above, the growth of the economy of North Sumatra fluctuates from year 2014-2017 then increased in the year 2018-2019. In 2019, economic growth in North Sumatra of $5.22 \%$ increase of $0.04 \%$ of the year 2018 by $5,18 \%$. 20142019 economic growth in North Sumatra low, ie in the year 2015 amounted to $5,10 \%$. According to data from the District/City, the economic growth in 2014 is the highest in the District of Deli Serdang of of $7.67 \%$ and the lowest in the Coal District of $4.20 \%$. In 2015 the highest economic growth in Mandailing Natal Regency by $6,22 \%$ and the lowest in the Coal District of $4,11 \%$. In 2016, the highest economic growth in the City of Medan by $6,27 \%$ and the lowest in North Tapanuli Regency amounted were 
4.12\%. In 2017 the highest economic growth in the District Mandaling Christmas by $6,09 \%$ and the lowest in the Coal District of $4,11 \%$. In 2018, the highest economic growth in the City of Gunungsitoli of $6.03 \%$ and the lowest in North Tapanuli Regency to $4.35 \%$. In the year 2019 the highest economic growth in the City of Gunungsitoli by $6,05 \%$ and the lowest in the District of Coal amounted to 4.35 percent. Economic growth increase the supply of resources needed for human development. The increase in resources along with proper resource allocation and distribution opportunities are increasingly widespread, especially employment opportunities will encourage the development of better human beings.
Apart from the economic growth, poverty can also affect Human Development Index. Poverty is a global issue faced by many countries in the world, including Indonesia. According to Todaro (in Widyawati, 2020) poverty is widespread and high numbers is the core of all development problems. Poverty is a multidimensional problem related to various aspects of life and human livelihoods, both in the aspect of economic, political, social, cultural, psychology, technology, and others that are interrelated (Jonah in Widyawati, 2020). Therefore, the efforts to overcome poverty take time, strategy, and resources that need to be synergized to solve it.

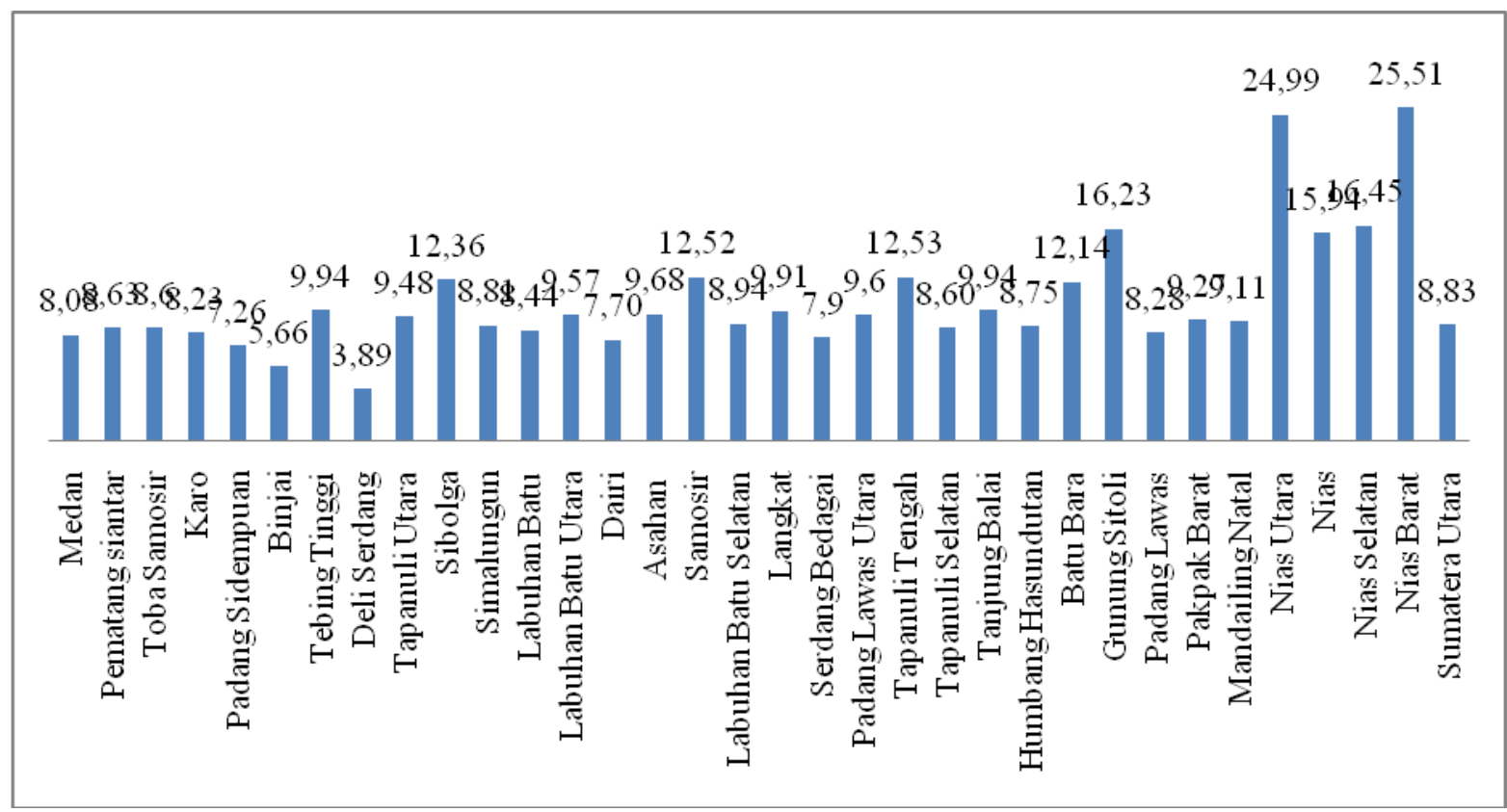

Source: The Central Bureau Of Statistics North Sumatra, 2020

Figure 1.4 Percentage of Poor people North Sumatra per District/City 2019(Percent)

Based on the above chart, in 2019 the percentage of the poor population is the highest in North Nias by $24,99 \%$ and the percentage of poor people the best that is in Deli Serdang by $3,89 \%$. The percentage of poor people of North Sumatra Province is ranked 17th if compared with all Provinces in Indonesia amounted to $8,83 \%$. The percentage of poor people in North Sumatra down $0.39 \%$ from the previous year by $9.22 \%$. The percentage of the poor population can affect the Human
Development Index if the number of poor people in an area is high then it will lose the Human Development Index. This happens because the poor have limited access to their needs included in the meet the needs in the field of education and health (Mirza, 2011). Therefore, the implication will be able to lose the Human Development Index.

The government has an important role in the allocation, distribution and stabilization. In order to improve the quality of human development, the government 
issued Law Number 32 Year 2004 on Regional Government and Law No. 33 of 2004 on Financial Balance between Central and Local Government. Government spending or investment that is intended for human development. Government spending is a reflection of the measures taken by the government (Baeti, 2013). Fiscal policy government area right through the regional Revenue and Expenditure Budget is expected to increase the Index of Human Development so that can improve the welfare of society.

Table 1.3: Direct expenditure per Capita Area of North Sumatra per District/ City 2019 (Thousand Rupiah)

\begin{tabular}{|c|c|c|}
\hline No. & Kab/Kota & 2019 \\
\hline 1 & Medan & $1.315,586$ \\
\hline 2 & Pematang Siantar & $1.760,752$ \\
\hline 3 & Toba Samosir & $2.182,086$ \\
\hline 4 & Karo & $1.351,016$ \\
\hline 5 & Padang Sidempuan & $1.909,284$ \\
\hline 6 & Binjai & $1.583,264$ \\
\hline 7 & Tebing Tinggi & $2.456,226$ \\
\hline 8 & Deli Serdang & 766,5425 \\
\hline 9 & Tapanuli Utara & $1.756,172$ \\
\hline 10 & Sibolga & $3.757,525$ \\
\hline 11 & Simalungun & 928,05598 \\
\hline 12 & Labuhan Batu & $1.289,604$ \\
\hline 13 & Labuhan Batu Utara & $1.552,998$ \\
\hline 14 & Dairi & $1.639,907$ \\
\hline 15 & Asahan & $1.001,7604$ \\
\hline 16 & Samosir & $2.893,108$ \\
\hline 17 & Labuhan Batu Selatan & $1.467,156$ \\
\hline 18 & Langkat & 763,051 \\
\hline 19 & Serdang Bedagai & $1.087,169$ \\
\hline 20 & Padang Lawas Utara & $1.802,337$ \\
\hline 21 & Tapanuli Tengah & $1.543,408$ \\
\hline 22 & Tapanuli Selatan & $2.550,559$ \\
\hline 23 & Tanjung Balai & $1.817,185$ \\
\hline 24 & Humbang Hasundutan & $2.239,614$ \\
\hline 25 & Batu Bara & $1.336,661$ \\
\hline 26 & Gunung Sitoli & $2.314,078$ \\
\hline 27 & Padang Lawas & $1.798,537$ \\
\hline 28 & Pakpak West & $6.200,821$ \\
\hline 29 & Mandailing Natal & $1.368,622$ \\
\hline 30 & Nias Utara & $3.154,628$ \\
\hline 31 & Nias & $3.099,363$ \\
\hline 32 & Nias Selatan & $1.729,879$ \\
\hline 33 & Nias West & $4.477,762$ \\
\hline
\end{tabular}

Based on the above table, in 2019 direct shopping area for the highest per capita in the Districts/Cities in North Sumatra in Pakpak West Rp.6.200.821 and low in Langkat Rp.763.051. According to (Rakhmawati, 2017) the magnitude of the figures of expenditure and the allocation of appropriate and fair evenly should be able to improve the human development in the area.
The magnitude of the spending areas indicate the magnitude of the role of government to human development (Soebeno in Mailendra, 2009). Although the direct expenditure per capita area of Langkat including low if compared with the Regencies/Cities in North Sumatra, the value of the Human Development Index area Langkat entrance in the status are. This is where the importance of the role of government in regulating the allocation of the expenditure of the region to the right of the target and the effect on human development.

Human development in North Sumatra status is high when compared with some of the Provinces in Indonesia. However, this does not guarantee all Districts/Cities in North Sumatra has the quality of construction of a good human being. Regardless of the growth of the Human Development Index, the problems faced today is the disparity. Because the Index of Human Development Districts / Cities in North Sumatra uneven, there is a status of very high, high and medium. Even there that are in the category of cartilage due to being in the lowest number in the status are. Considering only the City of Medan the Development Index of Human is at the status is very high, i.e. of 80.97 index, the numbers are pretty lame when compared with the Nias West namely 61,14 index in 2019. Why human development in the Districts/Cities in North Sumatra has not been evenly distributed and whether the economic growth, poverty as well as direct expenditures per capita affects human development are not the same in each District/City.

\section{LITERATURE REVIEW Human Development}

Human development as a process to expand the options for the residents. In the concept of the residents placed it as the final destination (the ultimated end) while development efforts is seen as a means of (principal means) to accomplish that goal. To ensure the achievement of the goal of 
human development, the four main things that must be considered is the productivity, equity, sustainability, empowerment (UNDP in Lumbantoruan, 2015).

\section{Development Index}

The Human Development index (HDI) is an indicator of the level of human development in a region, which is calculated through three fundamental to the development of human longevity and healthy life, Knowledge and decent living Standard/Expenses.

\section{Economic Growth}

Economic growth is an overview of the impact of government policies implemented in particular in the field of economics. Economic growth is the growth rate which is formed from a variety of sectors of the economy that are not directly describe the level of economic growth that occurs. For the region, this indicator is important to determine the success of development in the future (Sirojuzilam, 2010:10).

\section{Poverty}

Poverty is a condition when a person or group of people is not able to fulfill their basic rights to maintain and develop a life of dignity. Fundamental rights, among others: the fulfillment of the needs of food, health, education, employment, housing, clean water, land, natural resources and the environment, safety of the treatment or the threat of violence and the right to participate in social life-political (Bappenas, 2004).

\section{Shopping Area}

Shopping area which includes all expenditures from the cash account of the general areas that reduce the equity of the fund smoothly, which is the obligation of the area in a one-year budget that will not be obtained payment back by area. Shopping area as meant in the Regulation of the Minister of home Affairs No. 13 Year 2006 on Regional Financial Management Guidelines of article 31 paragraph (1) is used in the framework of the implementation of government affairs under the authority of the provincial or district/city consists of obligatory and optional affairs and the affairs are handled in a part or a particular field which can be implemented between the government and the local government or between government area defined by legislation.

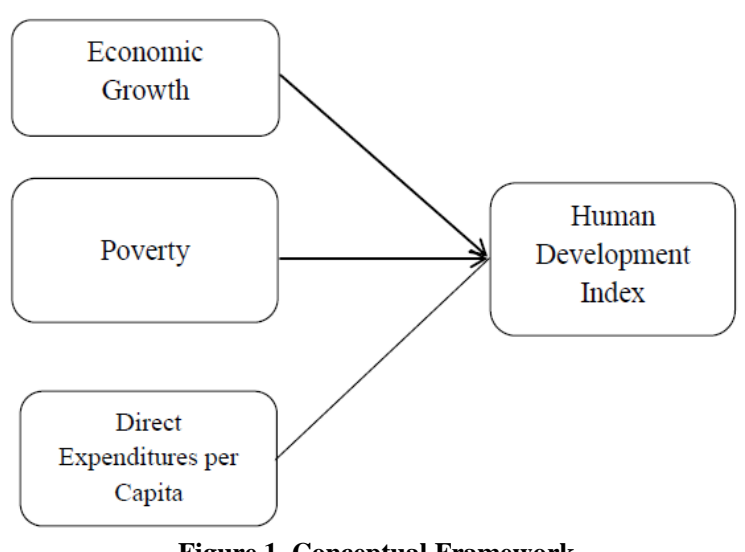

Figure 1. Conceptual Framework

\section{Hypothesis}

1. Economic growth has a positive effect on Human Development Index in North Sumatra

2. Poverty effect negatifterhadap Human Development Index in North Sumatra

3. Direct spending per Capita has a positive effect on Human Development Index in North Sumatra

\section{MATERIAL AND METHODS}

This research, the study using quantitative data. Quantitative Data is data that is numeric or numeric. Research conducted in the Province of North Sumatra in the series six years (2014-2019) to see the Influence of Economic Growth, Poverty and Direct Spending per Capita Human Development Index in North Sumatera.

This study uses secondary data with the analysis of panel data. Panel Data used in this study combined time series data from the year 2014 to 2019 and cross section a taken from 33 Districts/Cities in North Sumatra obtained from The Central Bureau Of Statistics North Sumatra. Using data on the Human Development Index, GDP at 
constant prices, percentage of poor people and direct expenditure per capita in North Sumatra.

Methods of data analysis in this research using analysis of panel data is a combination of time series data and cross section. Time series Data is Data gathered from time to time against an individual while the cross section data is data that is collected in one time to many individuals (Gujarati, 2011:28). The method of panel data is a method used to perform the empirical analysis with the behavior of the data is dynamic. Cross section Data in this study is the data obtained from 33 Districts/Cities in North Sumatra $(\mathrm{N}=33)$, while the time series data in this research is data taken from the year 2014, 2015, 2016, 2017, 2018, $2019(\mathrm{~T}=6)$ that produces 198 observations.

\section{RESULTS AND DISCUSSION Analysis Of The Influence Of Economic Growth On Human Development Index}

Based on the results of the regression show that the value of the coefficient of Economic Growth of 0,617410 with a probability of 0,0020 . Probability < alpha 0.05, then Economic Growth has a negative influence to the Human Development Index. Neither the value of the regression coefficient 0,617410 that shows if Economic Growth was up $1 \%$ then it will lose the Human Development Index in 33 districts/cities in North Sumatra in the year 2014-2019 by 0,617410 index.

The results of this study are not in accordance with the theory of Kuznets who said that one of the characteristics of the growth of the modern economy is the high output per capita. The high output growth have an impact on the change in the pattern of consumption. In other words, the increasing economic growth it will increase the output per capita income and changing consumption patterns and increasing the human development index.

Investment prop up the economy in 2018. Investment growth of $10.25 \%$ with the contribution of $3.01 \%$ of the economic growth on an annual basis. The high investment growth is driven by the acceleration of the construction of strategic infrastructure in 2018, such as the port of Kuala Tanjung and street to tol Medan Kualanamu - Lubuk Pakam -High Cliff.The government undertook the construction of infrastructure investment such as toll roads to drive economic growth, but on the education and health sector is not considered in such a way which is intended to improve the Human Development Index.

In the year 2019 in North Sumatra, the number of schools, teachers, doctors, hospitals, health centers is still not evenly distributed. The year 2019 the number of schools in North Sumatra as much as 13.488. The number of schools majority located in the City of Medan amount 1.484 and the smallest number contained in Sibolga City that is 58 and PakPak West 90. The number of teachers most in the City of Medan as much as 23.141 and the smallest in Distric PakPak West tota1. 221 and the City of Sibolga amount of 1340. North Elementary school in North Sumatra on average in the year 2019 amounted to 173. The highest ratio found in the City of Sibolga that 299 students per school and the City of Medan as much as 273 students per school. While the ratio of the smallest found in Samosir Regency that is equal to 96 students per school. At the level of secondary education, ratio of students to school is equal to 237 students per school. The highest ratio found in the City of Pematang Siantar, namely 399 pupils for each school and the lowest are in Distric Pakpak West, namely 112 pupils for each school. Meanwhile, the ratio of high School students against the school of 303 pupils per school. The ratio is highest in Humbang Hasundutan Regency, namely the 480 students per school and the lowest in the District of Padang Lawas North of 172 students for each school.

Then the number of hospitals in North Sumatra as many as 183 . The number of hospital is the largest in the City of 
Medan amounted to 54 with 41 health and 962 doctor. To Distric Nias the West does not have a hospital there are only 8 health centers and 15 doctors. Nias regency, South Tapanuli Regency, Distric Tapanuli the Middle, Distric Tapanuli North, Distric Dairi, Distric Humbang Hasundutan, Distric PakPak West, Distric Samosir, Distric Nias North and Kota Gunung Sitoli only have 1 hospital.

Improving the quality and participation of the school population surely must be balanced with the provision of physical education and teachers are offered as well as the availability of health facilities specialized hospital is a major factor in supporting the improvement of quality of life. The construction was carried out uneven so the growth can not be felt until all layers of society and affect the economic growth negatively affect the Human Development Index.

Table 4.8: Percentage distribution of GDP According to the Field of Business On The Basis Of Constant Prices Of 2010 (Percent) 2017-2019

\begin{tabular}{|l|l|l|l|}
\hline Field Of Business & $\mathbf{2 0 1 7}$ & $\mathbf{2 0 1 8}$ & $\mathbf{2 0 1 9}$ \\
\hline Agriculture, Forestry, and Fisheries & 24,88 & 24,81 & 24,79 \\
\hline Mining and Quarrying & 1,32 & 1,32 & 1,32 \\
\hline Processing Industry & 19,03 & 18,76 & 18,05 \\
\hline Procurement of Electricity and Gas & 0,14 & 0,14 & 0,14 \\
\hline Water supply, Waste Management, Waste, and Recycling & 0,10 & 0,10 & 0,10 \\
\hline Construction & 12,55 & 12,58 & 12,83 \\
\hline Wholesale and Retail trade, Repair of Cars and Motorcycles & 17,52 & 17,68 & 17,97 \\
\hline Transportation and Warehousing & 4,71 & 4,75 & 4,78 \\
\hline The provision of Accommodation and Eating and Drinking & 2,31 & 2,37 & 2,45 \\
\hline Information and Communication & 2,65 & 2,74 & 2,85 \\
\hline Financial and Insurance services & 2,99 & 2,90 & 2,81 \\
\hline Real Estate & 4,23 & 4,24 & 4,22 \\
\hline The Services Of The Company & 0,90 & 0,91 & 0,92 \\
\hline Government administration, Defense and Compulsory Social security & 3,17 & 3,20 & 3,29 \\
\hline Educational Services & 2,01 & 2,03 & 2,02 \\
\hline Health services and Social Activities & 0,96 & 0,97 & 0,97 \\
\hline Other Services & 0,51 & 0,52 & 0,52 \\
\hline PDRB & $\mathbf{1 0 0 , 0 0}$ & $\mathbf{1 0 0 , 0 0}$ & $\mathbf{1 0 0 , 0 0}$ \\
\hline
\end{tabular}

Based on the sources of economic growth in North Sumatra, 2019 the economy of North Sumatra is still dominated by the Field of Agriculture, Forestry, and Fisheries of $24,79 \%$. Agriculture still become the foundation of the economic drivers, arguably North Sumatra is still dependent on the agricultural sector. This sector is to encourage economic growth, but not to use or recruit Human Resources well, because the majority of working in the sector is labour that does not have the standard of a good education which can further affect the Human Development Index. In 2019, workers in the agricultural sector the most, namely the graduates of the SD of 1.071.034 soul. Junior high school of 580.664 soul, and graduated high School by 659.397 the soul, because it is economic growth that happens not to offend the
Human Development Index, so the Index of Human Development are not realized with better

This research is in line with research conducted by Wisdom J Rahmadhani, Idris (2019) research on the Influence of the Cost of Construction, the Independence of the Fiscal and Economic Growth To Human Development in West Sumatra. The research results show economic growth a significant negative effect on human development index in West Sumatra in the year 2013-2017. This study is also in line with research conducted by Islama Desrindra, Neng Murialti, Della Hilia Anriva (2016) research on the Factors that Affect Human Development Index in the Province of Riau. The research results show that economic growth is a significant negative effect on human development 
index in the Province of Riau in the year 2010-2014.

\section{Analysis Of The Influence Of Poverty On Human Development Index}

Based on the results of the regression show that the value of the coefficient of Poverty by $-0,384983$ with probability 0,0000 . Probability < alpha 0.05 , then Poverty has a negative influence and significant impact on the Human Development Index. Neither the value of the regression coefficient $-0,384983$ that shows if Poverty fell by $1 \%$ will increase the Human Development Index in 33 districts/cities in North Sumatra in the year 2014-2019 by 0,384983 index.

The results of this study in accordance with the theory of the vicious circle of poverty proposed by Nurkse, which explains the poverty that ensnare the poor people in poor countries. Real income leads to low saving ability and the lack of capacity of capital to investments that have an impact on low productivity and ultimately lead to the weakness of the level of income, with the weakness of the income level of the community is not able to meet the basic needs/staple so that the other needs such as education and health neglected. The increasing number of poor people hence the need of education and health are not met and so on will affect the achievement of the Human Development Index.

The percentage of poor people in North Sumatra has decreased every year. In 2014, the percentage of poor people of North Sumatra by $9,85 \%$ will be $8,83 \%$ in 2019. The reduced the population of the poor signifies the rising level of income, this is a good thing to improve the Human Development Index because people can access their needs, especially in the fulfillment of the needs of, especially in the field of education and health.

This research is in line with research conducted by Denni Sulistio Mirza (2012) research on the Influence of Poverty, Economic Growth, and Capital Expenditure On Human Development Index in Jawa
Tengah Tahun 2006-2009. The research results show poverty a significant negative effect on human development index in Central Java. This study is also in line with research conducted by Mita Pangestika, Edy Widodo (2017) research on the Factors that Affect Human Development Index in the District/City D.I. Yogyakarta 2011-2015. The research results show poverty a significant negative effect on human development index in the District/City D.I. Yogyakarta.

\section{Analysis of the Influence of Direct Expenditure per Capita Human Development Index}

Based on the results of the regression show that the value of the coefficient of Direct Expenditure per Capita by 0,001545 with probability 0,0000 . Probability < alpha 0.05, then Direct Spending per Capita has a positive and significant influence on Human Development Index. Neither the value of the regression coefficient 0,001545 that indicates if Direct Spending per Capita rose 1000 Dollars then it will raise the Human Development Index in 33 districts/cities in North Sumatra in the year 2014-2019 by 0.001545 index.

This is in line with the theory raised by Rostow that connects that government spending is government investment by providing facilities and infrastructure such as education, health, transport infrastructure and so on (Sirozujilam, 2010:9). Direct shopping area consists of the direct spending of employees, direct expenditures for goods and services, and direct spending capital. With regard to the Human Development Index which is a policy made by the government for the sake of improving human development is not only based on the quality of human resources but also in infrastructure. Infrastructure needs to be improved such as the construction of schools and education program, free services and free health programs as well as the construction of roads, especially on the cross roads between regions as access to 
people in the trade so the can help to improve the income per capita in North Sumatra.

The role of government is very important to improve the Human Development Index. The government should make policies to budget very carefully to improve the welfare of the community according to the conditions, the peculiarities, and the potential advantages of the area. The government carefully and efficiency in the preparation and allocation of budget. Direct shopping areas are prioritized to protect and improve the quality of life of the community in the efforts to fulfill the obligation of the area which is manifested in the form of improved basic services, education, provision of health care facilities, social facilities and public facilities that you deserve as well as develop social security by considering the analysis of the standard of shopping, standards, measure performance and minimum service standards established in accordance with the legislation (ACT No.32 of the Year 2004).

This research is in line with research conducted by Zuraida Rakhmawati, Mohamad Rafki Nazar, Djusnimar Zultilisna (2017) which examines the Influence of Economic Growth, Local Revenue and Local Spending On Human Development Index in the Province of West Java 2010-2014, the results of the research indicate local spending significant positive effect on human development index in the province of West Java. Research Nur Isa Prastowo (2012) that examines the Analysis of Factors that Influence Human Development Index, the results of the research indicate local spending significant positive effect on human development index in the Province of Central Java in the years 2002-2009.

\section{CONCLUSIONS AND \\ RECOMMENDATIONS CONCLUSIONS}

Based on the explanation and analysis conducted in the previous chapter, the conclusions that can be drawn in this research, among others:

1. The test results show that Economic Growth is a significant negative effect on Human Development Index in North Sumatera years 2014-2019.

2. The test results show that Poverty is a significant negative effect on Human Development Index in North Sumatra years 2014-2019.

3. The test results show that the Direct Expenditure per Capita significant positive effect on Human Development Index in North Sumatra years 20142019.

\section{RECOMMENDATIONS}

Suggestions from the research that has been done is as follows:

1. To increase the Index of Human Development in the districts/cities in North Sumatra, refers to the quality growth, by increasing the consumption of the community through the People's Business Credit, application cards prakerja, ease of halal certification for micro and small enterprises. Achieve economic Growth in line with the human development, economic growth is expected to be accompanied by equitable development to improve equitable development in the education and health sectors in all Districts/Cities, such as the construction of schools, hospitals, and clinics.

2. To increase the Index of Human Development in the districts/cities in North Sumatra, the local government is expected to focus on alleviating poverty with the revitalization of the rural development and urban. Efforts in expanding the opportunities of the poor in the fulfillment of basic rights by providing space and business space for the poor, developing the housing environment that is healthy to involve the community, to develop the industrial rural areas, as well as develop a center for information services in rural areas, 
increase the community's access to health services and education.

3. To increase the Index of Human Development in the districts/cities in North Sumatra, the government should enlarge the composition of the budget provides public goods and services in the amount of more and of better quality. Of government spending, government spending in the form of investment in the fund or fund facilities and public goods in particular education, health care, electricity, clean water, provision of facilities and infrastructure to social activities such as a welfare program and public health services.

Acknowledgement: None

\section{Conflict of Interest: None}

\section{Source of Funding: None}

\section{REFERENCES}

1. Alan, A. Altman, Y.Roussel. 2008. Employee Training Needs and Perceived Value of Training in the Pearl River Delta of China: A Human Capital Development Approach. Journal of European Industrial Training, 32(1), 19-31.

2. Bhakti, Nadia Ayu. Istiqomah. Suprapto. 2012. Analisis Faktor-Faktor yang Mempengaruhi Indeks Pembangunan Manusia di Indonesia Periode 2008-2012. Jurnal Ekonomi dan Keuangan. Volume 18, Nomor 4, Desember 2014 : 452-469.

3. Badan Perencanaan Pembangunan Nasional. 2004. Strategi Nasional Penanggulangan Kemiskinan.

4. Badan Perencanaan Pembangunan Nasional. 2018. Analisis Wilayah dengan Kemiskinan Tinggi. Kedeputian Bidang Kependudukan dan Ketenagakerjaaan.

5. Badan Pusat Statistik. 2006. Badan Pusat Statistik Indonesia.

6. Badan Pusat Statistik. Statistik Keuangan Pemerintah Daerah Provinsi Sumatera Utara 2014-2019. Badan Pusat Statistik Provinsi Sumatera Utara.
7. Badan Pusat Statistik. Sumatera Utara dalam Angka 2014-2019. Badan Pusat Statistik Provinsi Sumatera Utara.

8. Badan Pusat Statistik. 2018. Indeks Pembangunan Manusia 2018. Badan Pusat Statistik Indonesia.

9. Badan Pusat Statistik. 2019. Indeks Pembangunan Manusia Sumatera Utara 2019. Badan Pusat Statistik Sumatera Utara.

10. Badan Pusat Statistik Kabupaten Humbang Hasundutan. 2018. Indeks Pembangunan Manusia Kabupaten Humbang Hasundutan 2018. Badan Pusat Statistik Kabupaten Humbang Hasundutan.

11. Baeti, Nur. 2013. Pengaruh Pengangguran, Pertumbuhan Ekonomi, dan Pengeluaran Pemerintah Terhadap Pembangunan Manusia Kabupaten/Kota di Provinsi Jawa Tengah Tahun 20072011. Economics Development Analysis Journal. EDAJ 2 (3) (2013).

12. Desrindra, Islami. Murialti, Neng. Anriva, Della Hilia. 2016. Analisis Faktor Yang Mempengaruhi Indeks Pembangunan Manusia di Provinsi Riau. Jurnal Akuntansi dan Ekonomika, Vol.6 No.2, Desember 2016.

13. Firdaus, M. 2018. Aplikasi Ekonometrika Untuk Data Panel dan Time Series. Bogor: IPB Press.

14. Ginting, Charisma Kuriata. Lubis, Irsad. Mahalli, Kasyful. 2008. Analisis Pembangunan Manusia di Indonesia dan Faktor-Faktor yang Mempengaruhinya. Wahana Hijau. Jurnal Perencanaan \& Pengembangan Wilayah. Vol.4, No.1, Agustus 2008.

15. Gujarati, Damodar. 2011.Dasar-Dasar Ekonometrika. Terjemahan: Mangunsong, R.C.Jakarta: Salemba Empat, Buku 1, Edisi 5.

16. Gujarati, Damodar. 2012. Dasar-Dasar Ekonometrika. Terjemahan: Mangunsong, R.C.Jakarta: Salemba Empat, Buku 2, Edisi 5.

17. Hanapiah, Ali. 2011. Analisis Investasi Modal Manusia Dalam Perspektif Pendidikan Dan Pelatihan. Jatinagor: IPDN. 
18. Hasyim, Ali Ibrahim. 2016. Ekonomi Makro. Depok: Kharisma Putra Utama.

19. Jhingan, M. L. 2018.Ekonomi Pembangunan dan Perencanaan. Depok: Raja Grafindo Persada.

20. Karya, Detri. Syamsuddin, syamri. 2016. Makro Ekonomi: Pengantar Untuk Manajemen. Jakarta: Rajawali Pers.

21. Kementerian Keuangan Republik Indonesia Direktorat Jenderal Perimbangan Keuangan. 2018. Modul Peningkatan Kapasitas Pengelolaan Keuangan Daerah.

22. Kuncoro, Mudrajat. 2004. Otonomi dan Pembangunan Daerah. Jakarta: Erlangga.

23. Lumbantoruan, Eka Pratiwi. Hidayat, Paidi. 2011. Analisi Pertumbuhan Ekonomi dan Indeks Pembangunan Manusia (IPM). Jurnal Ekonomi dan Keuangan Vol.2 No.2.

24. Madden, D. dan Smith, F. 2000. Poverty in Ireland, 1987-1994: A Stochastic Dominance Approach. The Economic and Social Review, Vol. 31, 187- 214

25. Mangkosoebroto, Guritno. 2001. Ekonomi Publik Edisi Ketiga. Yogyakarta: BPFE UGM.

26. Mankiw, N. Gregory. 2006. Makro Ekonomi. Terjemahan: Fitria Liza, Imam Nurmawan. Jakarta: Erlangga.

27. Mirza, Denni Sulistio. 2012.Pengaruh Kemiskinan, Pertumbuhan Ekonomi, dan Belanja Modal Terhadap Indeks Pembangunan Manusia di Jawa Tengah Tahun 2006-2009. Economics Development Analysis Journal 1 (1) (2012).

28. Murni, Asfia. 2006. Ekonomika Makro. Bandung: Refika Aditama.

29. Noviansyah, Helmi. Rosyadi. Yacoub Yarlina. 2019. Kemampuan Konsumsi Rumah Tangga, Investasi dan Pengeluaran Pemerintah Dalam Menjelaskan Indeks Pembangunan Manusia (IPM) di Kalimantan Barat. Jurnal Ekonomi Daerah Vol.7, No.1.

30. Nurkholis, Afid. $2018 . \quad$ Teori Pembangunan Sumberdaya Manusia. EconPapers.

31. Pangestika, Mita. Widodo, Edy. 2017. Analisis Regresi Panel Terhadap FaktorFaktor yang Mempengaruhi Indeks
Pembangunan Manusia di

Kabupaten/Kota DI Yogyakarta. Seminar Nasional dan The 4th Call for Syariah Paper.

32. Pratowo, Nur Isa. 2012. Analisis FaktorFaktor yang Berpengaruh Terhadap Indeks Pembangunan Manusia. Jurnal Studi Ekonomi Indonesia.

33. Ranis, Gustav. 2004. Human Development and Economic Growth. Center Discussion Paper, No.887.

34. Rahmadhani, Hikmah J., Idris. 2019. Pengaruh Kemahalan Konstruksi, Kemandirian Fiskal dan Pertumbuhan Ekonomi Terhadap Indeks Pembangunan Manusia di Sumatera Barat. Jurnal Kajian Ekonomi dan Pembangunan, Volume 1, Nomor 2, Maret 2019, Hal 301-308.

35. Rakhmawati, Zuraida. Nazar, Mohamad Rafki. Zultilisna, Djusnimar. 2017. Pengaruh Pertumbuhan Ekonomi, Pendapatan Asli Daerah dan Belanja Daerah Terhadap Indeks Pembangunan Manusia (Studi Pada Kota dan Kabupaten di Provinsi Jawa Barat Periode 20102014). e-Proceeding of Management : Vol.4, No.2 Agustus 2017 Page 1709.

36. Rastogi, P. N. 2002. Knowledge Management and Intellectual Capital as a Paradigm of Value Creation. Human Systems Management, 21(4).

37. Rustariyuni, Surya Dewi. 2012. Pengaruh Gini Ratio, Konsumsi Non Makanan per Kapita, Belanja Daerah dan Laju Pertumbuhan Ekonomi Pada Indeks Pembangunan Manusia Kabupaten/Kota di Provinsi Bali Periode 2004-2012. Piramida Vol. X No.1:45-55.

38. Romer, P. M. 1990. Endogenous Technological Change. Journal of Political Economy, 98(5), 71-102.

39. Rosen, H. S. 1999. Public Finance. New York: McGraw-Hill.

40. Sirojuzilam. Mahalli, Kasyful. 2010. Regional Pembangunan, Perencanaan, dan Ekonomi. Medan: USU Press.

41. Suryana. 2000. Ekonomi Pembangunan: Problematika dan Pendekatan. Jakarta: Salemba Empat.

42. Sutamihardja. 2004. Perubahan Lingkungan Global. Bogor: Program Studi Pengelolaan Sumber Daya Alam 
dan Lingkungan Sekolah Pascasarjana, IPB.

43. Todaro, Michael P. Smith, Stephen C. 2003. Pembangunan Ekonomi (edisi kedelapan, jilid I). Jakarta: Erlangga.

44. Todaro, Michael P.Smith, Stephen C. 2006. Pembangunan Ekonomi (edisi kesembilan, jilid I). Jakarta: Erlangga.

45. Todaro, Michael P.Smith, Stephen C 2011. Pembangunan Ekonomi (edisi kesebelas, jilid I). Jakarta: Erlangga.

46. UNDP. 1990. Human Development Report 1990. New York: Oxford University Press.

47. Widyawati, Dewi. Muchlisoh, Siti. 2020. Penerapan Metode ELL-Counterfactual
Untuk Pemerataan Kemiskinan Level Kecamatan dan Desa/Kelurahan. Seminar Nasional Official Statistics 2020:Statistics in the New Normal : a Challenge of Big Data and Official Statistics

48. Yusri. 2011. Analisis Determinan Indeks Pembangunan Manusia di Provinsi Aceh.

How to cite this article: Pardede NW, Irsad, Rujiman. Analysis of factors that affecting to human development index in North Sumatra. International Journal of Research and Review. 2021; 8(4): 453-467. DOI: https://doi.org/10.52403/ijrr.20210455 